\title{
Histological analysis and the blood flux in kidneys submitted to different periods of ischemia/reperfusion ${ }^{1}$
}

\author{
Análise histológica e do fluxo sanguíneo em rins submetidos a períodos distintos de isquemia/ \\ reperfusão
}

\begin{abstract}
Fernando Meyer', Denise Sbrissia e Silva", Giovana Marina Bombonatto ${ }^{\mathrm{III}}$, Juliana Navarro Lizana ${ }^{\mathrm{IV}}$, Luiz Felipe Dziedricki ${ }^{\mathrm{V}}$, Michele Lonardoni Krieger ${ }^{\mathrm{VI}}$

IPhD, Associate Professor, Urology Division, Head Department of Urology, Cajuru University Hospital, PUCPR, CuritibaPR, Brazil. Main author, supervised all phases of the study. Provided guidelines for the surgical interventions. Responsible for conception of the study and critical revision.

IIGraduate student, Medical school, PUCPR, Curitiba-PR, Brazil. Helped with technical procedures and collection of study informations.

IIIResident, Department of Clinics, Evangelico University Hospital, FEPAR, Curitiba-PR, Brazil. Surgical proceduces. Acquisition and interpretation of data and manuscript writing.

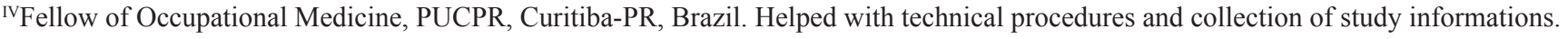

${ }^{v}$ Resident, Department of Gynecology and Obstetrics, Santa Brigida Maternity Hospital, Curitiba-PR, Brazil. Helped with technical procedures and collection of study informations.

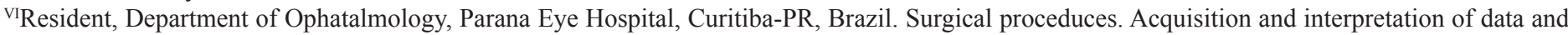
manuscript writing.
\end{abstract}

\begin{abstract}
PURPOSE: Evaluate the renal blood flow by using a laser flow meter, Laserflow Vasamedics ${ }^{\circledR}$, after the ischemia/reperfusion in two different times of the arterial renal vessel clamping.

METHODS: The renal blood flow was evaluated by using a laser flow meter after two different times of ischemia/reperfusion procedure, 30 and 60 minutes. It was used 20 Wistar male rats, divided in two groups of 10 rats: Group A (30 minutes of ischemia on the left kidney, with later analysis of the blood flow in 1,5 and 20, after the renal reperfusion start) and Group B (60 minutes of ischemia on the left kidney, with later analysis of the blood flow in 1,5 and 20 minutes, after the renal reperfusion start).

RESULTS: In the first minute, there were not significant differences between the two groups $(\mathrm{p}=0.789)$. In the 5 th minute there were not significant differences also, but there was a tendency $(\mathrm{p}=0.068)$. In the 20th minute, there was a significant difference between the 2 groups ( $\mathrm{p}=0.022$ ). When the means are observed, it is possible to notice that Group A has a larger flux than Group B.

CONCLUSION: The kidneys submitted to 30' of ischemia/reperfusion are subject to a larger restitution of the blood flow in comparison to the Group which had a longer time.
\end{abstract}

Keywords: Ischemia. Reperfusion. Kidney. Rats.

\section{RESUMO}

OBJETIVO: Avaliar o fluxo sanguíneo renal, por meio do fluxômetro a laser Laserflow Vasamedics ${ }^{\circledR}$, após a realização de isquemia/ reperfusão em dois tempos diferentes de clampeamento da artéria renal.

MÉTODOS: O fluxo sanguíneo renal foi avaliado por meio do fluxômetro a laser, após a realização de isquemia/reperfusão em dois tempos diferentes, 30 e 60 minutos. Foram utilizados 20 ratos Wistar machos, que foram subdivididos em dois grupos de 10 ratos. Grupo A: isquemia do rim esquerdo por 30 minutos e posterior análise do fluxo sangüíneo nos períodos de 1,5 e 20 minutos após o início da reperfusão renal. Grupo B: isquemia do rim esquerdo por 60 minutos e posterior análise do fluxo sangǘneo renal nos períodos de 1, 5 e 20 minutos após o início da reperfusão renal.

RESULTADOS: No $1^{\circ}$ minuto, não houve diferença significativa entre os grupos $(\mathrm{p}=0,789)$. No $5^{\circ}$ minuto, não houve diferença significativa entre os grupos $(\mathrm{p}=0,068)$, mas houve uma tendência. No $20^{\circ}$ minuto, houve uma diferença significativa entre os grupos $(\mathrm{p}=0,022)$. Observando as médias, percebe-se que o grupo A tem fluxo maior do que o grupo B. CONCLUSÃO: Os rins submetidos a 30 minutos de isquemia/reperfusão estão sujeitos a restituição maior do fluxo sanguíneo em comparação aos que sofrem isquemia por um tempo superior, conforme descrito na literatura mundial.

Descritores: Isquemia. Reperfusão. Rim. Ratos. 


\section{Introduction}

The ischemia/reperfusion injury (IR) can be defined as a whole of alterations due to privation and re-establishment of the oxygen supply to tissues and organs. It is a complex phenomenon which involves not only intracellular effects, but also an inflammatory response to the injury.

The pathogenesis of the ischemia/reperfusion is not completely understood. There are evidences which relates it with the decrease of mithocondrial ATP production, loss of the selective permeability of the cell membranes, increase of intracellular sodium and calcium leading the renal cell to injury or death.

A renal injury caused by ischemia makes relation with different medical areas, being essential to the Renal Surgery, Vascular and Transplantation.

The lateness in re-establishing the renal function after the transplantation results in oliguria, increase of the immunogenicity of the graft and episodes of acute rejections. These situations might be related to the donator and the kidney receptor (pre-renal, renal and post-renal factors associated to the transplanted kidney).

Experimental studies evidenced that both the ischemia and blood flow restitution in ischemically injured kidneys after hypothermic preservations, activate a complex sequence of events which sustains the renal injury and have a central role in the late kidney's function development ${ }^{1-3}$.

Previous researches in animal models had demonstrated that the consequences of ischemia/reperfusion depend on the duration, resulting in biochemical alterations and even cellular necrosis. Thompson et $a l .{ }^{4}$, in a retrospective human study, had evaluated the impact of ischemia time in patients with only one kidney submitted to open partial nephrectomy. They concluded that 20 to 35 minutes are, respectively, the maximum time for the lonely kidney tolerate hot ischemia and cold ischemia. Even with such many studies, we observed that there is not a consensus in the literature about the relation to the maximum hot ischemia period that the kidney does not suffer irreversible injuries.

It is known that the consequences of the ischemia in the different tissues depends on its duration, moreover many injuries are developed during the stage of re-oxygenation reperfusion of the tissue. The mitochondria are important targets of injuries done by the ischemia and reperfusion process ${ }^{5}$. Inside this organelle there is a decrease of NADH, ADP/ATP and ATP synthetase activities, besides increasing the phospholipase $\mathrm{A}_{2}$ activity. Furthermore, there is also an acute accumulation of calcium and free radicals production by the mitochondria. The association between these events might be responsible to the injuries and cellular death due to the reperfusion, possibly because of the transition phenomenon of internal mitochondrial membrane permeability ${ }^{1}$.

Recent studies in the renal ischemia pathogenesis permit us to make a temporal relationship between the clinical stages and the cellular changes. Initially, the kidney is exposed to ischemia, than the renal functions decrease and the parenchyma injuries start. The intracellular depletion of ATP is intense, prevailing epithelial and endothelial injuries: starting the production of reactive oxygen species and activation of inflammatory mechanisms. The intrarenal mechanisms of protection are requested and if the ischemia is interrupted, there is a complete recuperation in this stage. On the contrary, there will be larger damages, mainly after the reperfusion ${ }^{6}$.

The reperfusion injury can be measured by many mechanisms, including the production of reactive oxygen species, cellular displace, microvascular compression, polimorphonuclear leukocytes and hypercoagulability. The reperfusion leads to the congestion and red blood cell accumulation by the introduction of reactive oxygen species in the compressed vessels ${ }^{2}$.

The maximum hot ischemia time before the occurrence of irreversible injuries continues to be a discussion point. Unfortunately there are not pre-operatories or intra-operatories methods to evaluate the real damage. The surgeons must keep their efforts to maintain the ischemia time as little as possible. We developed our project aiming to appraise the differences between the renal blood flow after distinct times of ischemia.

\section{Methods}

This article has the approval of the Pontifical Catholic University of Parana Ethical Committee.

In this experimental study, 20 male Wistar (Rattus norvegicus albinus, Rodentia mammalia) rat were used. They had 90 days of life and 250 to $300 \mathrm{~g}$ of weight in mean. They were divided in two groups of 10 rats: Group A (30 minutes of ischemia on the left kidney, with later analysis of the blood flow in 1, 5 and 20 minutes, after the renal reperfusion start) and Group B (60 minutes of ischemia on the left kidney, with later analysis of the blood flow in 1, 5 and 20 minutes, after the renal reperfusion start).

The work had initiated with Group A. It was done an anesthetic induction, followed by a median laparotomy, exploring the abdominal cavity, indentifying and dissecting the left renal pediculus. After that, the venous and arterial left vessels were occluded with a Bulldog type clamp for 30'. Later on the ischemia time, the clamp was taken out and the reperfusion was started, after 1 minute the laser flow meter was positioned in the superior, 
medium and inferior regions of the left kidney to measure the respective blood flux. The measures were repeated in the $5^{\text {th }}$ and $20^{\text {th }}$ minutes (Figure 1).

The same procedures were done in Group B, however the clamping time of the left renal arterial vessel was 60 minutes.

After this process, the rat were submitted to euthanasia by giving the anesthetic in a three times higher dose. The data obtained were statistically analysed.

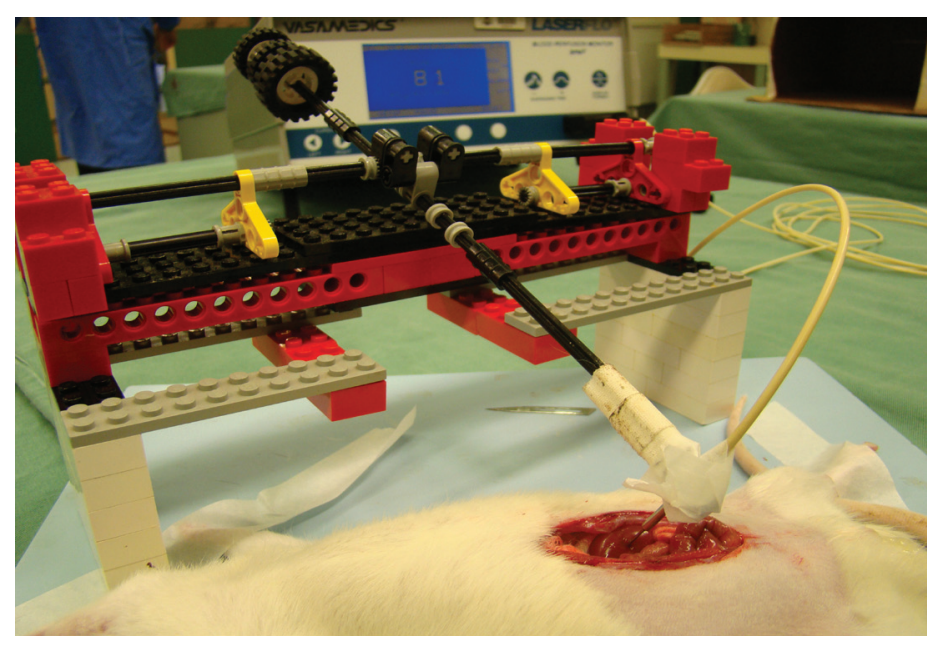

FIGURE 1 - Position of the flow meter to measure the renal blood flux after ischemia period.

\section{Results}

The results obtained consisted in the values of the renal flow from 10 rats from Group A and 9 rats from Group B. During the anesthetic procedure, one rat from the second Group deceased.

The results were expressed in means, medians, minimal values, maximum values and standard deviations. To compare the 2 Groups in relation to the mean flow, it was used the $t$ Student test for independent samples. The comparison of the evaluation moments inside each Group was done by using the variance analysis with repeated measures. The normality condition of the variables were evaluated with the Shapiro-Wilks test. The values $\mathrm{p}<0.05$ indicated statistical significance. The data were organized in Excel worksheet and analysed with the computer program Statistica v.8.0 (Table 1).
TABLE 1 - Group A and B renal blood flow in the $1^{\text {st }}, 5^{\text {th }}$ and $20^{\text {th }}$ minute.

\begin{tabular}{c|c|c|c|c|c|c|c|c}
\hline Moment & Group & N & Mean & Median & Minimum & Maximum & $\begin{array}{c}\text { Standard } \\
\text { Deviation }\end{array}$ & p Value \\
\hline FLOW_1 & $\mathrm{A}$ & 10 & 28.7 & 22.6 & 9.7 & 51.6 & 14.3 & \\
\hline & $\mathrm{B}$ & 9 & 27.0 & 28.1 & 13.0 & 45.1 & 13.1 & 0.789 \\
\hline FLOW_5 & $\mathrm{A}$ & 10 & 28.8 & 31.3 & 4.9 & 43.2 & 13.5 & \\
\hline & $\mathrm{B}$ & 9 & 18.9 & 18.3 & 8.2 & 34.4 & 7.4 & 0.068 \\
\hline FLOW_20, & $\mathrm{A}$ & 10 & 33.8 & 34.4 & 6.8 & 73.0 & 19.0 & \\
\hline & $\mathrm{B}$ & 9 & 16.7 & 14.7 & 8.7 & 34.0 & 7.3 & 0.022 \\
\hline
\end{tabular}

In the first minute (Figure 2), there was not significant difference between the Groups $(p=0.789)$. In the $5^{\text {th }}$ minute (Figure $3)$, there were not significant differences between the Groups $(p=0.068)$, but it was observed a tendency. In the $20^{\text {th }}$ minute (Figure 4), there was a significant difference between the groups $(p=0.022)$. By analyzing the means, it is possible to note that Group A has a larger flow than Group B.

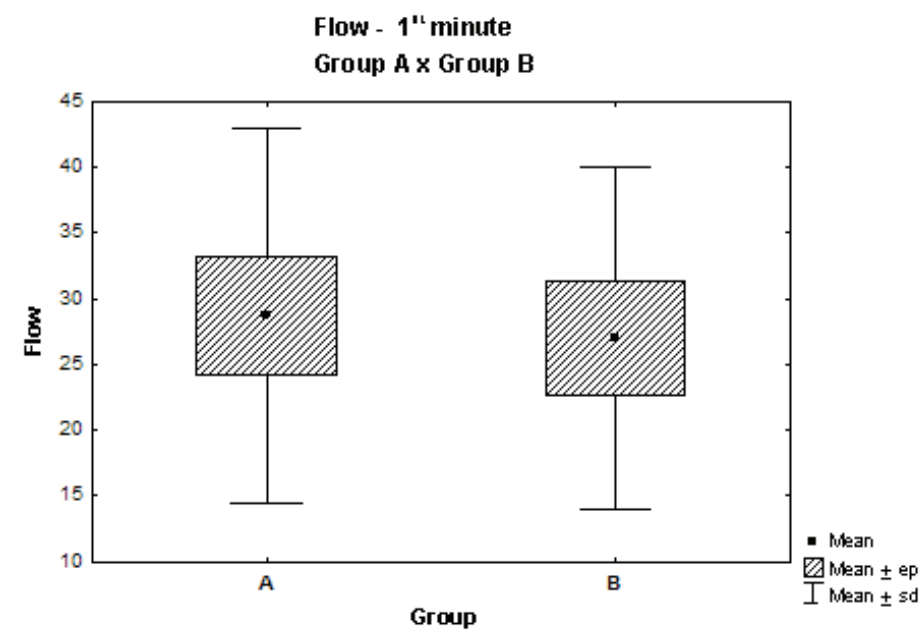

FIGURE 2 - Flow in the $1^{\text {st }}$ minute Group A x Group B.

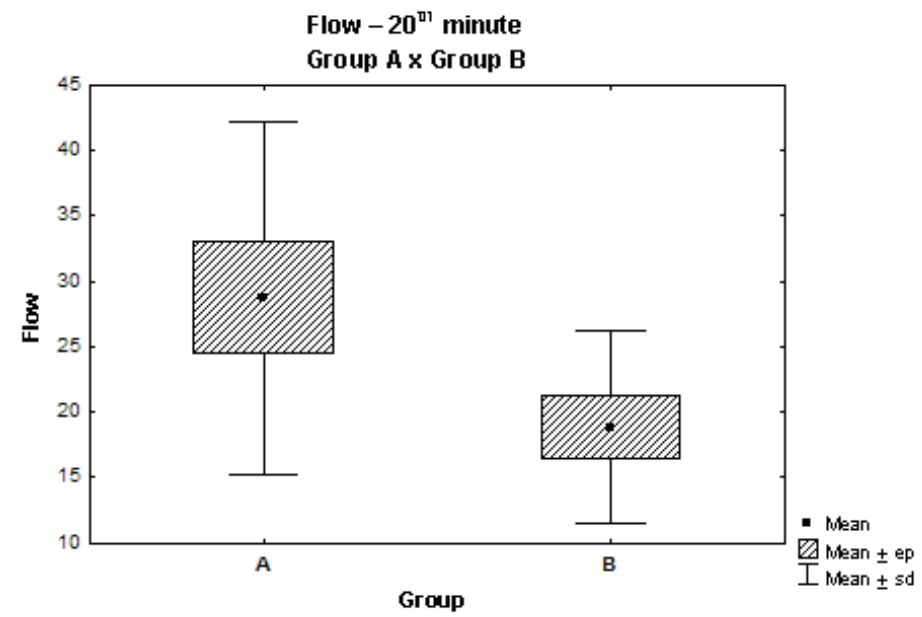

FIGURE 3 - Flow in the $5^{\text {th }}$ minute Group A x Group B. 


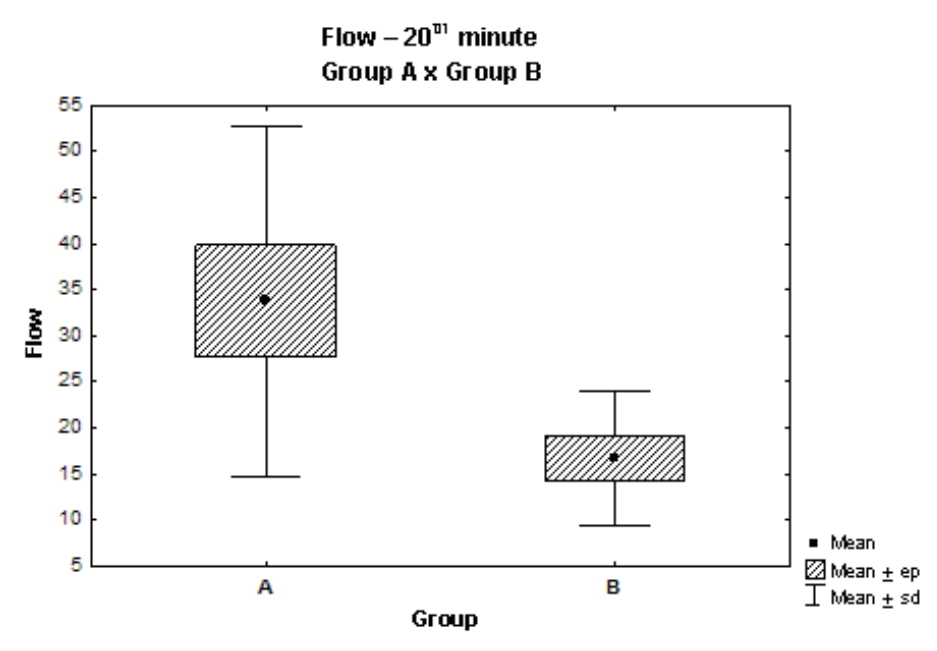

FIGURE 4 - Flow in the $20^{\text {th }}$ minute Group A x Group B.

\section{Discussion}

The ischemia plays an important role in many different per operatory clinical situations. Although the blood revascularization to the ischemic organ is essential to prevent the irreversible cellular injury, the reperfusion might worsen the damage caused by the isolated ischemia. The ischemia period itself is sufficient to cause a significant renal loss of function, but the injury caused by the reperfusion showed to be more harmful than the isolated ischemia because it is produced a greater local inflammatory response leading to systemic damages ${ }^{2}$.

The rat's kidney exposed to chronic ischemia develops diffuse tubular atrophy, interstitial fibrosis and good glomerular preservation. The only rare injury in humans but frequent in rat is the intersticial inflammation ${ }^{6}$.

The kidneys are more resistant to ischemia than other organs, in opposite to the liver which its histology is precociously affected. Many studies in animals demonstrated the renal tolerance to ischemia for more than 30 minutes, but there is a concerning about the total recuperation of the renal function after all this period of time ${ }^{2}$.

In a study with dogs it was observed that a period longer than $30^{\prime}$ could lead to a renal recuperation? ${ }^{7}$ In study with pigs, Humphreys et al. ${ }^{8}$ observed a renal function deterioration in kidneys submitted to a ischemia period of 75 minutes.

The time of ischemia could influence in the animals' survival. In our study, the Group A showed $100 \%$ of survival and Group B gave the evidence of $90 \%$. Similar results were found in a study which the rate of rat survival submitted to a mean ischemia period of 37.5 minutes while the animals who had died were proceeded to a mean time of 81 minutes $^{1}$.

It was observed in our research that after the first and $5^{\text {th }}$ minute of reperfusion, there were not found significant results in both groups. Although in the flux analysis after the $20^{\text {th }}$ minute of the left arterial renal clamp withdrawal, significant evidences were observed. The rat submitted to 30' of ischemia showed a greater flow in comparison to the animals submitted to 60 minutes. This information demonstrates that the longer is the ischemia time, the greater is the renal damage, as the blood flux to the organ survival is lower.

The absence of significant results at 20' may be due to the technique found to adapt the flow meter to the kidney, mainly in the first minute.

It is not possible to conclude what was the most harmful mechanism to the kidney: the prolonged ischemia or the reperfusion.

The longer is the ischemia time, the intensive are the histological changes, increasing the percentage of cortical necrosis and the damage of the acute tubular necrosis. This situation was described by Alvaréz et al. ${ }^{2}$ which the Group A, of 30' of ischemia, showed a case of cortical necrosis with $100 \%$ of damage and the other Group, $10 \%$. There were observed four cases of cortical necrosis in the Groups of 45 and 90 minutes.

In the initial project, one of the objectives was to analyse more than the renal blood flow, but to evaluate the possible histopathological alterations in different times of ischemia. However, due to the difficulties in interpreting the laminas, the lack of comparative models and the unavailability of the lab pathologist, we chose to change the initial theme of the project. We observed that in the majority of the studies, the renal injuries are measured by biochemical parameters (creatinine and diuresis), energetical supply (ATP, ADP, AMP), histological alterations and others.

The results found in our project were compatible to literature and statistically significant, nevertheless the flow meter is not the ideal method to evaluate de vitality of the organs because it is subjected to many external bias, such as the rat movement, difficulty to adapt the equipment on the kidneys and delayed in measuring the stabilization of the flux. Moreover, the laser flow meter is not frequently mentioned in the literature as a method of analysis.

Even with the greater experience of the surgeons, the time limit of 30 minutes is still a safe border between irreversible injuries to the kidney when it has no proper cooling preservation.

It is necessary to make future studies to define which are the better parameters to measure the ischemia/reperfusion injury, 
moreover it is indispensable the development of methods to protect the kidneys during the lesions.

\section{Conclusion}

The 30 minutes of renal occlusion establishes a larger flux in comparison to the kidneys submitted to 60 minutes of

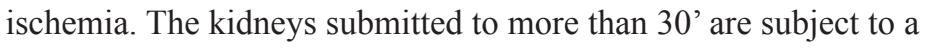
reduced organ survival.

\section{References}

1. Vijande AR. Estúdio de la carga energética celular en el transplante renal experimental con diferentes períodos de isquemia caliente. Actas Urol Esp. 2008;32(1):41-58.

2. Secin FP. Importance and limits of ischemia in renal partial surgery: experimental and clinical research. Adv Urol. 2008:102461.

3. Silva OC, Centurion S, Pacheco E. Basics aspects of the ischemia reperfusion injury and of the ischemic preconditioning. Acta Cir Bras. 2002;17(3):96-100.

4. Thompson RH, Frank I, Lohse CM, Saad IR, Fergany A, Zincke H, Leibovich BC, Blute ML, Novick AC. The impact of ischemia time during open nephron sparing surgery on solitary kidneys: a multiinstitutional study. J Urol. 2007;177(2):471-6.

5. Konopka LC, Jurach A. Experimental model for the study of chronic renal ischemia in rats: morphologic, histological and ultra-structural analysis. Acta Cir Bras. 2007;22(1):12-21.

6. Devarajan P. Update on mechanisms of ischemic acute kidney injury. J Am Soc Nephrol. 2006;17(6):1503-20.

7. Wickman JEA, Ward JP. Determination of the optimum temperature for regional renal hypothermia during temporary renal ischaemia. Br J Urol. 1975;47(1):17-24.

8. Humphreys MR, Castle EP, Lohse CM, Sebo TJ, Leslie KO, Andrews PE. Renal ischemia time in laparoscopic surgery: an experimental study in a porcine model. Int J Urol. 2009;16(1):1059.

\section{Correspondence:}

Fernando Meyer

Pontifícia Universidade Católica do Paraná (PUCPR)

Departamento de Urologia

Rua Portugal, 307

80510-280 Curitiba - PR Brasil

Tel.: (55 41)3074-7478

Fax: (55 41)3015-0303

fmeyer@onda.com.br

Received: April 14, 2011

Review: June 15, 2011

Accepted: July 18, 2011

Conflict of interest: none

Financial source: none

${ }^{1}$ Research performed at Department of Urology, Pontifical Catholic University of Parana (PUCPR), Curitiba-PR, Brazil. 